http://ejournal.upi.edu/index.php/jaz - e-mail:_jurnal_zonasi@upi.edu doi.org/10.17509/jaz.v4i2.32945

\title{
PENGARUH BENTUK GUBAHAN MASSA DINAMIS TERHADAP ESTETIKA DAN KENYAMANAN SPASIAL PADA BANGUNAN HOTEL U JANEVALLA
}

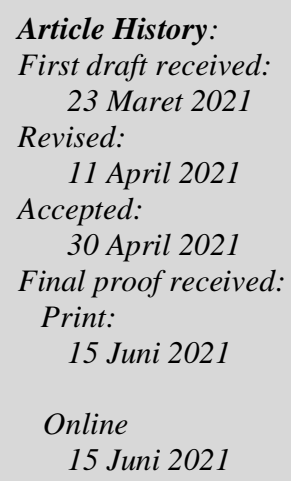

Jurnal Arsitektur ZONASI is indexed and listed in several databases:

SINTA 4 (Arjuna)

GARUDA (Garda Rujukan Digital)

Google Scholar

Dimensions

oneSearch

BASE

Member:
Crossref
RJI
APTARI
FJA (Forum Jurna Arsitektur)
IAI
AJPKM

\section{Pendahuluan}

Hotel merupakan salah satu bangunan komersial dengan fungsi akomodasi yang menyediakan jasa penginapan, makan dan minum, juga jasa pelayanan lainnya, serta harus memenuhi kriteria tertentu seperti standar ruang beserta kelengkapan isinya sesuai dengan kelasnya. Hotel diklasifikasikan menjadi berbagai jenis, salah satuya berdasarkan lokasi adalah city hotel yang berada di perkotaan, dengan bentuk yang

\author{
Trestyar Ambarani ${ }^{1}$ \\ Maharani Diadra Zulcy² \\ Rifky Rama Herlambang ${ }^{3}$ \\ Nur Laela Latifah ${ }^{4}$ \\ 1,2,3,4 Program Studi Arsitektur, Institut Teknologi Nasional, Bandung, Indonesia \\ Jl. PH.H. Mustofa No. 23 Bandung 40124 \\ Email: trestyara@mhs.itenas.ac.id \\ maharanidz@mhs.itenas.ac.id \\ ela@itenas.ac.id
}

\begin{abstract}
Hotel is a commercial building and the success of its design has a very positive impact on increasing its selling value. Generally, hotel buildings in cities or city hotels are designed based on the form follow function theory so that the interior space is functioning optimally, but the shape of the square block buildings that occur tends to look monotonous. In order to make the visual appearance more attractive, through the strategy of transforming the mass composition of the hotel to be dynamic, there will be a consequence where the layout and furnishings of the existing interior may reduce the spatial comfort (space) for the user. Another thing that must be tested from a dynamic mass composition is its aesthetic value in terms of proportion and scale. As a research case study, Hotel U Janevalla was chosen in Jl. Aceh No. 65 Bandung. The analysis was carried out in a comparative way between case studies and theory, both in terms of qualitative and quantitative. The benefit value of this research is an insight into how the dynamic mass composition of hotels influences the aesthetic value and spatial comfort of users in the bedroom.
\end{abstract}

Keywords: Hotel, Dynamic mass composition transformation, Aesthetics, Spatial comfort.

\begin{abstract}
Abstrak: Hotel adalah bangunan komersial dan keberhasilan desainnya berdampak sangat positif bagi peningkatan nilai jualnya. Umumnya bangunan hotel di kota atau city hotel dirancang berdasarkan teori form follow function agar ruang dalamnya berfungsi optimal, tetapi bentuk bangunan blok persegi yang terjadi cenderung terlihat monoton. Agar tampilan visualnya lebih menarik, melalui strategi transformasi gubahan massa hotel dibuat menjadi dinamis, maka timbul konsekuensi dimana dengan tata letak dan kelengkapan interior yang ada dapat terjadi kemungkinan berkurangnya kenyamanan spasial (ruang gerak) bagi pengguna. Hal lain yang harus diuji dari gubahan massa dinamis adalah nilai estetikanya ditinjau dari proporsi dan skala. Sebagai kasus studi penelitian, dipilih Hotel U Janevalla di Jl. Aceh No. 65 Bandung. Analisis dilakukan dengan cara komparatif antara kasus studi dengan teori, baik ditinjau dengan cara kualitatif maupun kuantitatif. Nilai manfaat dari penelitian ini adalah wawasan bagaimana pengaruh bentuk gubahan massa hotel yang dinamis terhadap nilai estetika dan kenyamanan spasial pengguna pada kamar tidur.
\end{abstract}

Kata Kunci: Hotel, Transformasi gubahan massa dinamis, Estetika, Kenyamanan spasial. 
umumnya berupa blok massa, bertingkat tinggi, dan dilengkapi lantai basement karena keterbatasan lahannya (Nurfadilah, 2016). Umumnya hotel didesain dengan cara modular, dimana terutama pada area kamar tidur terjadi pengulangan bentuk dasar denah persegi panjang dan dinding dibangun vertikal, sehingga terbentuk blok massa yang monoton. Di sisi lain, desain hotel dengan bentuk unik dapat memberi imagel persepsi tersendiri bagi pengguna terutama tamu hotel, sehingga secara positif meningkatkan nilai jualnya sebagai bangunan komersial. Salah satu cara untuk menghasilkan keunikan ini adalah melalui transformasi bentuk gubahan massa yang dinamis.

Bentuk adalah wujud struktur teratur suatu karya, yang dihasilkan melalui penataan dan koordinasi elemen dari komposisi, sehingga diperoleh citra yang logis dan konsisten. Secara 2 dimensi ada 3 bentuk dasar, yaitu lingkaran, segitiga, dan bujursangkar. Lingkaran bersifat memusat, introvert, dengan titik inersia visualnya berada di tengah. Segitiga bersifat stabil, tetapi bila dibalik dengan alas di atas dan puncak di bawah maka bersifat labil. Bujursangkar bersifat murni, rasional, dan simetris, dengan stabilitas diperoleh bila garisgaris sumbu dan diagonalnya berada dalam kondisi horizontal dan vertikal. Melalui pengaturan posisi, orientasi, dan inersia visual, elemen bentuk dasar ini akan menghasilkan komposisi dengan citra bentuk bersifat monoton teratur atau menjadi bersifat dinamis tak beraturan. (Ching, 2008).

Secara 3 dimensi, bentuk solid primer diperoleh dengan merubah dimensi atau memutar bentuk dasar. Ada 5 bentuk solid primer yaitu bola, tabung, kerucut, limas, dan kubus. Bola bersifat memusat dan stabil. Tabung bersifat stabil bila sumbunya dalam keadaan vertikal. Kerucut bersifat stabil tetapi menjadi labil bila puncaknya tidak berada di atas. Limas stabil dengan kondisi sisinya yang manapun dapat menjadi alas. Kubus bersifat statis, dan stabil dengan kondisi sisinya yang manapun menjadi alas. Variasi bentuk lain muncul melalui transformasi dimensional, transformasi subtraktif, dan transformasi aditif terhadap bentuk solid primer ini. Transformasi dimensional terjadi bila bentuk solid primenr mengalami perubahan dimensi dengan tetap mempertahankan identitas bentuknya. Transformasi subtraktif terjadi bila bentuk solid primer mengalami pengurangan volume dan sebaliknya transformasi aditif mengalami penambahan volume, sehingga dapat terjadi perubahan identitas bentuknya. (Ching, 2008).

Transformasi secara etimologis adalah adalah proses perubahan rupa baik bentuk, sifat, fungsi, dan sebagainya. Proses transformasi adalah suatu strategi arsitek dalam mencari bentuk baru. Melalui strategi ini, bentuk awal mengalami perubahan dan manipulasi sehingga menjadi bentuk unik yang baru dan berbeda dari sebelumnya. Antoniades dalam bukunya Poetics of Architecture menyatakan bahwa ada 3 strategi dalam proses transformasi yaitu strategi tradisional, strategi peminjaman/ borrowing, dan strategi dekonstruksi atau dekomposisi. Dari ketiga strategi ini, strategi tradisional bersifat paling sederhana seperti bentuk bangunan yang bertransformasi dengan hanya mengikuti bentuk bangunan atau site di sekelilingnya. Strategi peminjaman diperoleh dengan cara mengadop atau melakukan metafora atas bentuk pada karya lain, seperti arsitektur Kubisme yang menyadur aliran seni lukis Kubisme atau membuat gubahan massa dengan bentuk menyerupai piano. Strategi dekonstruksi atau dekomposisi terjadi melalui interpretasi suatu tema secara bebas dengan tetap mempertimbangkan fungsi bangunannya. (Najoan, 2011).

Estetika secara etimologis menurut KBBI adalah suatu cabang filsafat dimana manusia dengan kepekaannya memberi tanggapan berupa telaah terhadap seni dan keindahan. Estetika sangat penting posisinya dalam desain. Dalam penelitian terkait perwujudan arsitektur (Sani, 2015) terdapat pernyataan yang dikutip dari buku Architectural Composition oleh Krier bahwa sebuah bangunan dapat diterima sebagai karya arsitektur bila fungsi dan konstruksinya diperkaya oleh kepekaan estetika. Arsitektur identik dengan estetika, dan estetika diperoleh melalui komposisi berbagai elemen yang dapat dinilai visualnya, untuk itu diperlukan penerapan prisip-prinsip perancangan untuk menilai visual dari komposisi semua elemen tersebut. Seperti yang telah disebutkan oleh Ching dalam bukunya Arsitektur: Bentuk, Ruang, dan Susunannya, terdapat 7 prinsip perancangan yaitu proporsi, skala, keseimbangan, keserasian, kesatuan, irama, dan penekanan. (Sani, 2015). Proporsi dan skala saling terkait erat dan menempati hirarki teratas dalam 7 prinsip perancangan tersebut.

Proporsi adalah hubungan visual yang konsisten antar bagian/ komponen bangunan dengan keseluruhannya, sedangkan skala adalah hubungan matematis yang harmonis antara bangunan dengan sekitarnya (skala umum) dan antara bangunan dengan manusia (skala manusia). Proporsi yang diatur dengan baik dapat menghasilkan kualitas ruang dalam dengan tingkat kenyamanan spasial yang diinginkan. Kenyamanan spasial bagi pengguna adalah kenyamanan ruang gerak dan bersifat subyektif tergantung kondisi fisik pengguna. Umumnya digunakan standar manusia dewasa setinggi $175 \mathrm{~cm}$, kemudian ditinjau jangkauan (terkecil) dan jarak bersih (terbesar) pada ruang tersebut. (Hendrarto, 2012). Salah satu cara untuk menilai estetika melalui proporsi adalah menggunakan teori golden section yaitu perbandingan antara dua dimensi dimana yang terpendek dibagi dengan yang terpanjang, lalu yang terpanjang dibagi oleh jumlah kedua dimensi tersebut, dan sebagai nilai ideal adalah 0,618 (Ching, 2008). 
Sebagai bangunan komersial, keberhasilan fungsi ruang menjadi sangat penting agar sistem pelayanan hotel dapat berjalan sebagaimana mestinya, dimana fasilitas interior lengkap sesuai kelas hotel dan pengguna tetap dapat merasakan kenyamanan spasial. Salah satu cara untuk mencapai fungsi ruang yang optimal adalah dengan menerapkan form follow function pada proses desain.

Teori form follow function ini didengungkan oleh Louis Henry Sullivan pada tahun 1896, dimana bentuk bangunan harus mengikuti fungsi dari bangunan tersebut agar fungsinya bagi pengguna dapat berjalan dengan baik. Menurut teori ini, suatu dimensi, ruang, dan karakter pada bangunan harus mengedepankan dulu fungsi dari bangunan tersebut, dan bila fungsional tercapai maka otomatis estetetika akan diperoleh. (Loho, 2015). Untuk mencapai ruang yang optimal, sesuai dengan form follow function, terdapat beberapa strategi yang harus diterapkan pada desain yaitu sumbu bangunan yang jelas, tata letak ruang yang teratur, serta komposisi ruang yang proporsional dan logis. Hasilnya, bangunan berbentuk kotak sederhana dengan penataan massa yang simetris. (Agustin, 2018). Berdasarkan kenyataan yang terjadi, dengan penerapan form follow function justru pengamat merasakan monotonitas karena bentuk gubahan massa cenderung persegi dan tidak memiliki identitas masing-masing (Loho, 2015).

Form follow function memang mendukung fungsi ruang yang optimal, tetapi bila diterapkan dengan tidak hati-hati maka akan terjadi kemungkinan diperolehnya ekspresi visual monoton yang dapat menurunkan nilai jual bangunan. Di sisi lain, gubahan massa suatu bangunan dapat terlihat menarik bila bersifat dinamis dimana secara 2 dimensi bentuk dasar denahnya mengalami perubahan posisi dan orientasi, serta secara 3 dimensi bentuk solid primernya mengalami transformasi bentuk secara dimensional, subtraktif, atau aditif. Lalu dalam proses pencarian bentuk, strategi transformasi yang paling mendukung diperolehnya gubahan massa dinamis ini adalah strategi dekonstruksi atau dekomposisi.

Strategi dekonstruksi secara radikal melawan kaidah dalam arsitektur kalsik dan modern, lahir melalui eksplorasi dan kreatifitas dalam desain dengan didukung teknologi struktur dan bahan, dengan beberapa tokohnya yaitu Thom Mayne, Zaha M. Hadid, Frank O. Gehry, Enric Miralles, dan Eric O. Moss (Pujantara, 2015). Sebagian besar bentuk gerakan ini muncul di Amerika, dimana arsitek memiliki kesempatan lebih besar untuk bebas berekspresi. Bangunan dengan penerapan dekonstruksi memiliki kebebasan transformasi bentuk gubahan massa dengan ciri khas garis dan bidang miring, garis dan bidang lengkung bahkan dapat terpuntir, serta volume menggantung melalui struktur kantilever.

Bila bentuk gubahan massa dinamis diterapkan pada bangunan hotel, tampilan visualnya baik yang diamati dengan skala keseluruhan bangunan dari eksterior maupun skala interior, dapat memberi imagel persepsi estetika yang positif dan menarik minat, sehingga menaikkan nilai jualnya sebagai bangunan komersial. Di sisi lain, dengan diperolehnya bentuk massa bangunan dan bentuk denah ruang yang tidak kotak persegi, maka akan menimbulkan konsekuensi terhadap efektifitas penataan ruang dalam dimana dengan tata letak dan kelengkapan interior yang ada dapat terjadi kemungkinan kenyamanan spasial (ruang gerak) pengguna menjadi berkurang. Terkait efektifitas ruang dalam ditinjau dari perletakan furnitur (Putra, 2014) dalam penelitiannya menyatakan bahwa melalui penataan furnitur yang tepat sesuai dengan zona dan kebutuhan, disertai kesan spasial yang proporsional baik secara horizontal dan vertikal, maka diharapkan efektifitas ruang dalam dapat tercapai.

Ruang yang paling menentukan kepuasan pelayanan bagi tamu hotel sebagai fasilitas penginapan adalah kamar tidur. Kelengkapan dan tata letak interior pada kamar tidur ditentukan oleh kelasnya, dan ketersediaan jenis kelas kamar tergantung dari status bintang hotel. Berdasarkan (Westin, 2016) diperoleh gambaran bahwa makin tinggi kelas kamar hotel, maka makin luas ruangnya dan makin lengkap interiornya baik furnitur maupun saniternya.

Dalam penelitian ini akan dikaji apakah suatu hotel dengan bentuk gubahan massa dinamis dapat memenuhi nilai estika ditinjau dari proporsi dan skala, serta terutama pada kamar tidur dengan tata letak dan kelengkapan interior baik furnitur dan saniter yang sesuai dengan kelas kamarnya tetap memberikan kenyamanan spasial (ruang gerak) bagi pengguna.

Sebagai kasus studi yaitu Hotel U Janevalla di Jl. Aceh No. 65 Bandung, yang menerapkan transformasi bentuk gubahan massa dimana arsitek dengan mengangkat konsep menari (dancing) dan melalui strategi dekonstruksi atau dekomposisi menghasilkan bentuk yang dinamis dan estetis. Gubahan massa yang diolah dengan istimewa diharapkan meningkatkan nilai jual hotel berlantai 10 yang berstatus sebagai city hotel berbintang 4 ini. Sebagai konsekuensinya diperoleh denah lantai yang berbeda dengan tuntutan tata letak interior yang juga berbeda sesuai dengan space yang tersedia, dan hal ini dapat sangat berpengaruh terhadap kenyamanan spasial (ruang gerak) yang dirasakan pengguna, terutama di kamar tidur. Di hotel ini, kelas kamar dibagi menjadi 3 jenis yaitu superior, deluxe, dan grand deluxe. Diharapkan, melalui penelitian ini akan diperoleh wawasan bagaimana pengaruh bentuk gubahan massa yang dinamis pada desain hotel terhadap estika sebagai bangunan komersial serta kenyamanan spasial (ruang gerak) bagi pengguna terutama di kamar tidur. 


\section{Metode Penelitian}

Metoda analisis yang digunakan yaitu komparasi atau perbandingan antara kasus studi dengan teori, baik bersifat kualitatif maupun kuantitatif. Variabel penelitian mencakup transformasi bentuk denah dan gubahan massa, transformasi bentuk ruang dan massa bangunan, estika berdasarkan proporsi menggunakan teori golden section dan berdasarkan skala manusia pada bangunan dan kamar tidur, lalu terakhir kenyamanan spasial (ruang gerak) pengguna pada kamar tidur yang mengacu tata letak dan kelengkapan interior (furnitur dan saniter). Sebagai kesimpulan analisis dibuat pembobotan yang bersifat kuantitatif agar hasilnya lebih bersifat objektif.

\section{Hasil dan Pembahasan}

\subsection{Konsep Bentuk Gubahan Massa Hotel U Janevalla}

Hotel U Janevalla didirikan tahun 2013-2014 di Jl. Aceh No. 65 Bandung, pada lahan seluas 1.023,6 $\mathrm{m}^{2}$. Luas bangunan 7.5971,48 $\mathrm{m}^{2}$ dan luas terbangun $621,8 \mathrm{~m}^{2}$ dengan bentuk denah seperti huruf U. Bangunan city hotel dengan target pengguna pebisnis dan wisatawan ini terdiri atas 10 lantai meliputi ground floor, mezzanine, lantai $1 \mathrm{~s} / \mathrm{d}$ 7, dan pool plan. Jenis kamar tidur yang ditawarkan ada 3 yaitu superior, deluxe, dan grand deluxe.

Bentuk gubahan massa Hotel U Janevalla sangat unik. Bapak Budi Pradono selaku arsitek Studio Budi Pradono Architects (BPA) mengangkat konsep menari (dancing) dari tarian asli daerah Jawa Barat yaitu Jaipong, dengan melalui beberapa tahap transformasi bentuk dari aslinya Basic Form, yaitu tahap Pull \& Shift Increase Room Ambience, Suppling Form, dan terakhir tahap Dancing Mass, lihat Gambar 1.

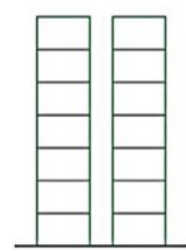

(1)

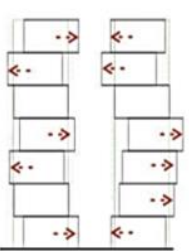

(2)

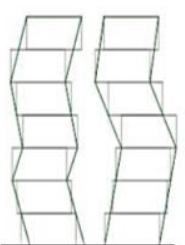

(3)

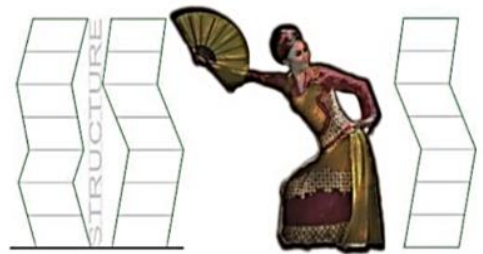

(4)
Keterangan:

(1) Basic Form

(2) Pull \& Shift Increase Room Ambience

(3) Suppling Form

(4) Dancing Mass

Gambar 1. Tahap Transformasi Bentuk Gubahan Massa Hotel U Janevalla Sumber: Budi Pradono Architect, 2018, diolah

Tabel 1. Analisis Konsep Bentuk Gubahan Massa Hotel U Janevalla

\begin{tabular}{|c|c|c|}
\hline No. & $\begin{array}{l}\text { Tahap } \\
\text { Transformasi }\end{array}$ & Analisis Konsep Bentuk Gubahan Massa \\
\hline 1. & Basic Form & $\begin{array}{l}\text { Bentuk solid primer kubus mengalami transformasi dimensional menjadi balok. } \\
\text { Berlaku teori form follow function yang mendukung fungsi hotel berjalan dengan baik, } \\
\text { terlihat keteraturan tata letak yang tinggi, tetapi tampilan visualnya terasa sangat monoton. }\end{array}$ \\
\hline 2. & $\begin{array}{l}\text { Pull \& Shift } \\
\text { Increase Room } \\
\text { Ambience }\end{array}$ & $\begin{array}{l}\text { Hasil transformasi tahap Basic Form mengalami transformasi dimensional dan pengaturan } \\
\text { posisi dengan cara digeser. Diperoleh peningkatan kualitas ruang, tetapi bentuk yang } \\
\text { diperoleh masih kurang dinamis. }\end{array}$ \\
\hline 3. & Suppling Form & $\begin{array}{l}\text { Hasil transformasi tahap Pull \& Shift mulai mengalami transformasi dengan strategi } \\
\text { dekonstruksi/ dekomposisi. } \\
\text { Diperoleh bentuk yang lebih fleksibel dan dinamis, tetapi belum memiliki tema. }\end{array}$ \\
\hline 4. & Dancing Mass & $\begin{array}{l}\text { Hasil transformasi tahap Suppling Form ditransformasikan dengan strategi dekonstruksi/ } \\
\text { dekomposisi yang mengangkat tema tertentu. } \\
\text { Diperoleh bentuk gubahan massa yang dinamis dengan tema tari Jaipong. } \\
\text { Ditinjau dari } 2 \text { dimensi, denah ruang yang semula memiliki bentuk persegi mengalami } \\
\text { pengaturan orientasi menjadi berbentuk jajaran genjang atau trapesium, sehingga selain } \\
\text { terjadi perubahan luas dan identitas bentuk juga dihasilkan komposisi yang dinamis tak } \\
\text { beraturan. } \\
\text { Ditinjau dari } 3 \text { dimensi, massa yang semula teratur bentuknya mengalami pemutaran, } \\
\text { sehingga selain terjadi perubahan volume dan identitas bentuk juga dihasilkan komposisi } \\
\text { yang dinamis tak beraturan dengan ditandai adanya garis dan bidang miring pada fasad. } \\
\text { Kesimpulan: Penerapan bentuk denah dan gubahan massa dinamis pada Hotel } \mathbf{U} \\
\text { Janevalla berhasil diterapkan dengan sangat baik, nilai } \mathbf{1 0 0 , 0 0 \%} \text {. }\end{array}$ \\
\hline
\end{tabular}




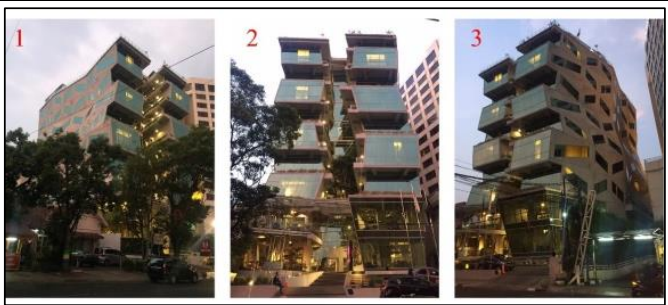

Gambar 2. Perspektif Hotel U Janevalla (Sisi Bangunan: 1. Barat Laut; 2. Selatan; 3. Tenggara) Sumber: dokumentasi penulis, 15 Oktober 2018

\subsection{Hasil Transformasi Bentuk Ruang dan Massa Bangunan pada Hotel U Janevalla}

Jumlah kamar yang dianalisis dibatasi hanya 1 buah dari masing-masing kelasnya, dengan pemilihan berdasarkan pertimbangan tertentu. Berikut Tabel 2 berisi analisis transformasi bentuk ruang.

Tabel 2. Analisis Transformasi Bentuk Ruang Hotel U Janevalla

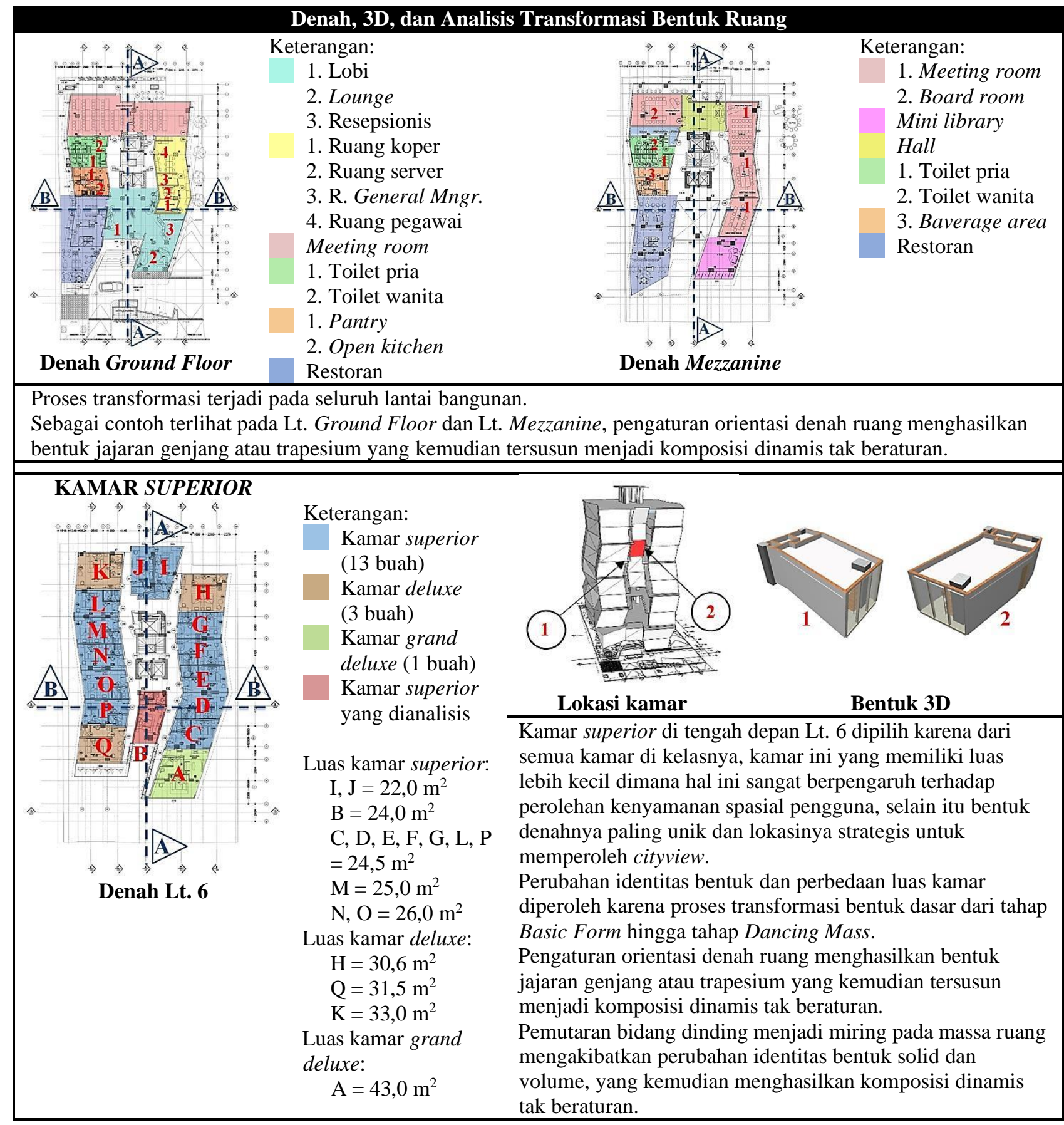


Tabel 2. Analisis Transformasi Bentuk Ruang Hotel U Janevalla (lanjutan)

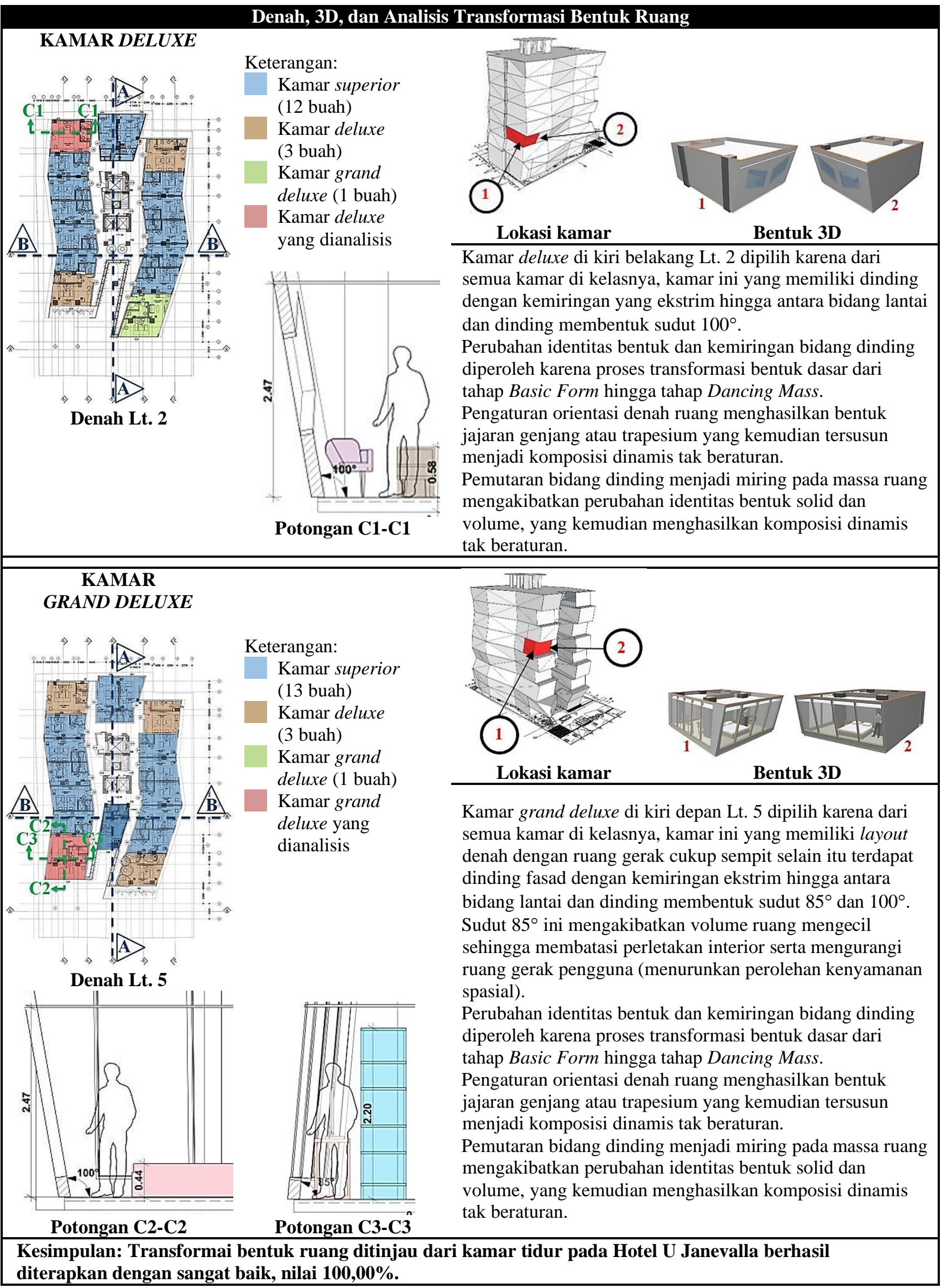

Sumber gambar denah: Budi Pradono Architect, 2018, diolah

Sumber gambar potongan dan 3D serta analisis: penulis, 2021 
Berikut Tabel 3 berisi analisis transformasi bentuk massa bangunan.

Tabel 3. Analisis Transformasi Bentuk Massa Bangunan Hotel U Janevalla

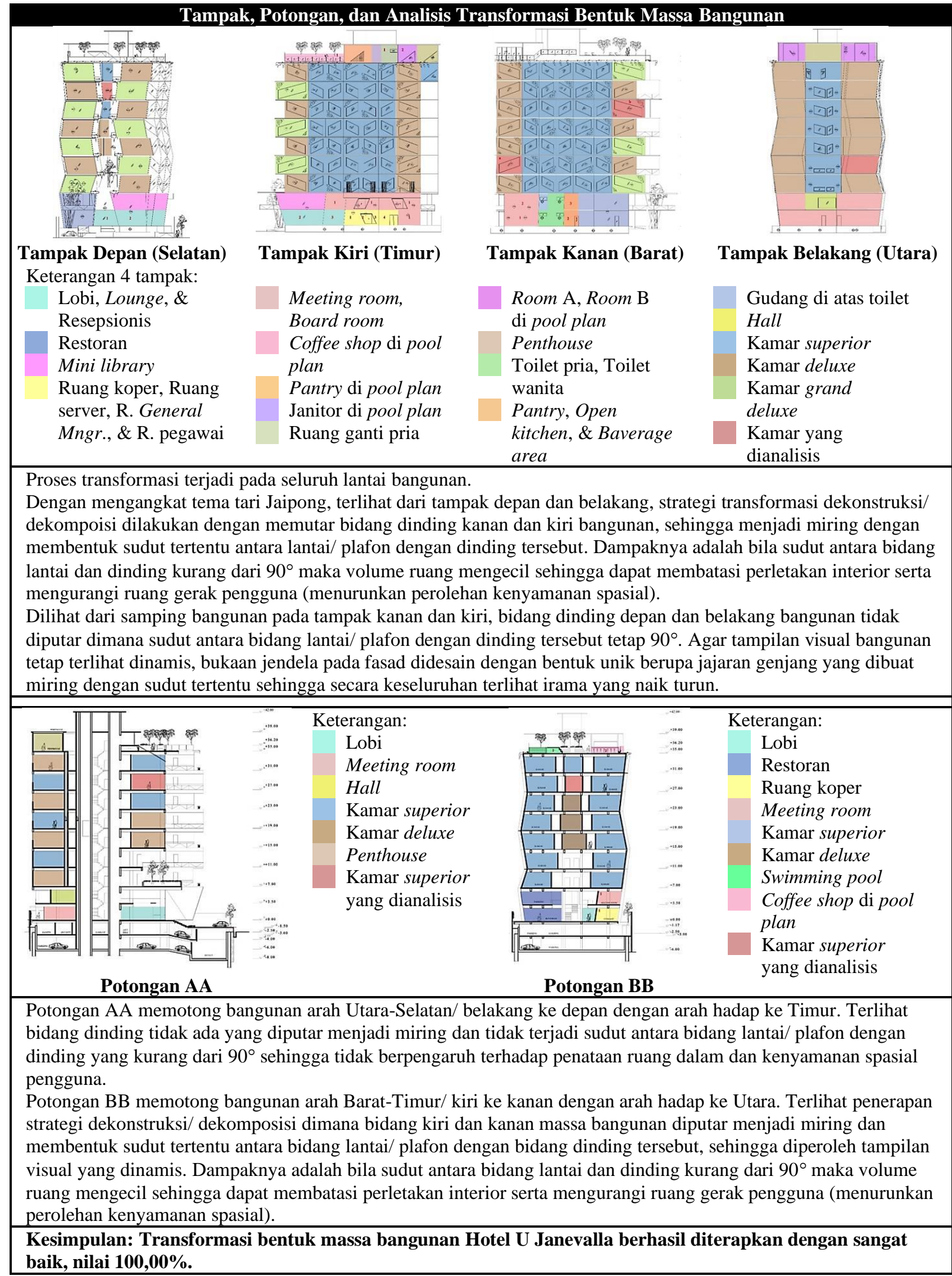




\subsection{Nilai Estetika Hotel U Janevalla Ditinjau dari Proporsi dan Skala}

Proporsi bangunan Hotel U Janevalla dihitung berdasarkan dimensi denah, tampak, potongan, dan 3D, sedangkan skalanya dibandingkan dengan tinggi manusia dewasa 1,75 m, lihat Tabel 4.

Tabel 4. Analisis Proporsi dan Skala Bangunan Hotel U Janevalla

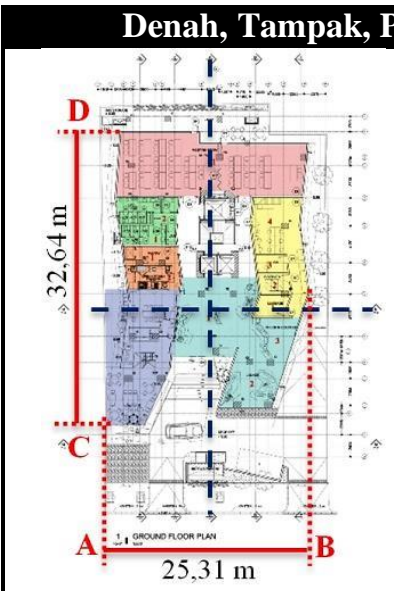

Denah Ground Floor

$\frac{\mathrm{AB}}{\mathrm{CD}}=\frac{25,31}{32,64}=0,7754$

$$
\begin{aligned}
\frac{\mathrm{CD}}{\mathrm{AB}+\mathrm{CD}} & =\frac{32,64}{25,31+32,64} \\
& =0,5632
\end{aligned}
$$

Rata-rata

$$
\begin{aligned}
& =(0,7754+0,5632) / 2 \\
& =0,6693
\end{aligned}
$$

Selisih

$$
\begin{aligned}
& =0,6693-0,6180 \\
& =0,0513
\end{aligned}
$$

Proporsi cukup baik

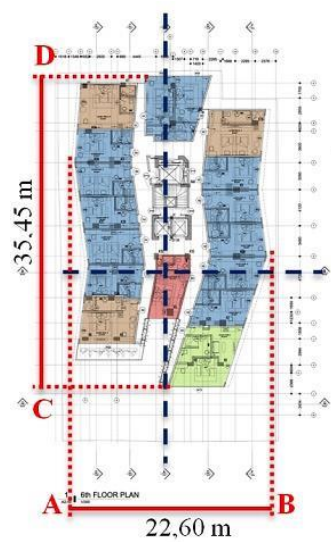

Denah Lt. 6

$$
\begin{aligned}
& \frac{\mathrm{AB}}{\mathrm{CD}}=\frac{22,60}{35,45}=0,6375 \\
& \begin{aligned}
\frac{\mathrm{CD}}{\mathrm{AB}+\mathrm{CD}} & =\frac{35,45}{22,60+35,45} \\
& =0,6107
\end{aligned}
\end{aligned}
$$

Rata-rata

$$
\begin{aligned}
& =(0,6375+0,6107) / 2 \\
& =0,6241
\end{aligned}
$$

Selisih

$$
\begin{aligned}
& =0,6241-0,6180 \\
& =0,0061
\end{aligned}
$$

Proporsi baik

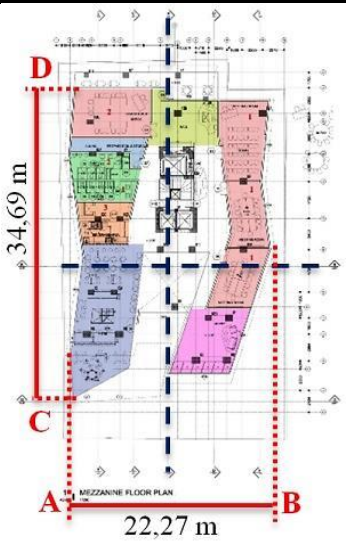

\section{Denah Mezzanine}

$\frac{\mathrm{AB}}{\mathrm{CD}}=\frac{22,27}{34,69}=0,6420$

$$
\begin{aligned}
\frac{\mathrm{CD}}{\mathrm{AB}+\mathrm{CD}} & =\frac{34,69}{22,27+34,69} \\
& =0,6090
\end{aligned}
$$

Rata-rata

$$
\begin{aligned}
& =(0,6420+0,6090) / 2 \\
& =0,6255
\end{aligned}
$$

Selisih

$$
\begin{aligned}
& =0,6255-0,6180 \\
& =0,0075
\end{aligned}
$$

Proporsi baik

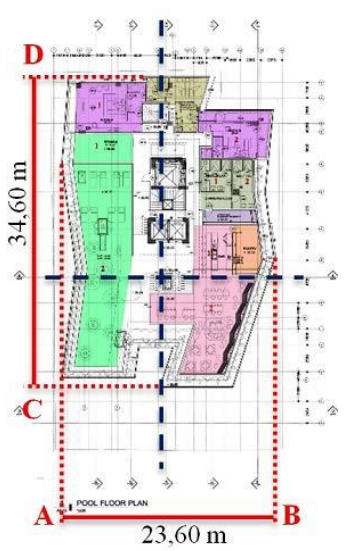

\section{Denah Pool Plan}

$\frac{\mathrm{AB}}{\mathrm{CD}}=\frac{23,60}{34,60}=0,6821$

$$
\begin{aligned}
\frac{\mathrm{CD}}{\mathrm{AB}+\mathrm{CD}} & =\frac{34,60}{23,60+34,60} \\
& =0,5945
\end{aligned}
$$

Rata-rata

$$
\begin{aligned}
& =(0,6821+0,5945) / 2 \\
& =0,6383
\end{aligned}
$$

Selisih

$$
\begin{aligned}
& =0,6383-0,6180 \\
& =0,0203
\end{aligned}
$$

Proporsi cukup baik

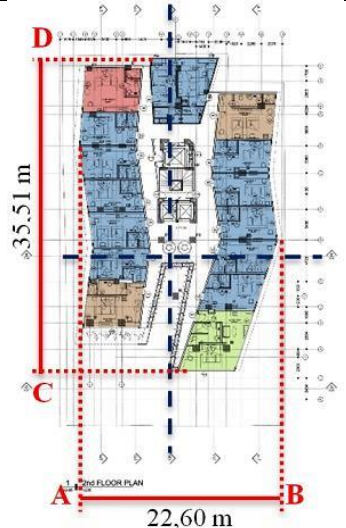

Denah Lt. 2

$\frac{\mathrm{AB}}{\mathrm{CD}}=\frac{22,60}{35,51}=0,6364$

$$
\begin{aligned}
\frac{\mathrm{CD}}{\mathrm{AB}+\mathrm{CD}} & =\frac{35,51}{22,60+35,51} \\
& =0,6111
\end{aligned}
$$

Rata-rata

$$
=(0,6364+0,6111) / 2
$$$$
=0,6238
$$

Selisih

$$
\begin{aligned}
& =0,6238-0,6180 \\
& =0,0058
\end{aligned}
$$

Proporsi baik

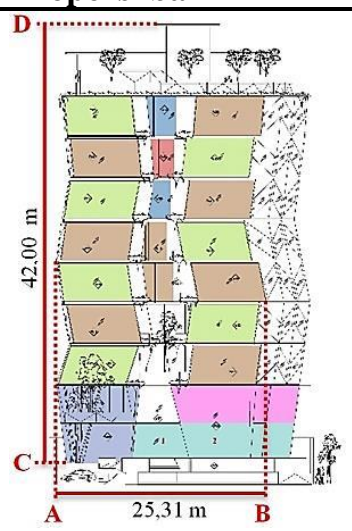

Tampak Depan (Selatan)

$$
\begin{aligned}
& \frac{\mathrm{AB}}{\mathrm{CD}}=\frac{25,31}{42,00}=0,6026 \\
& \begin{aligned}
\frac{\mathrm{CD}}{\mathrm{AB}+\mathrm{CD}} & =\frac{42,00}{25,31+42,00} \\
& =0,6240
\end{aligned}
\end{aligned}
$$

Rata-rata

$$
=(0,6026+0,6240) / 2
$$$$
=0,6133
$$

Selisih

$$
=0,6180-0,6133
$$$$
=0,0047
$$

Proporsi baik

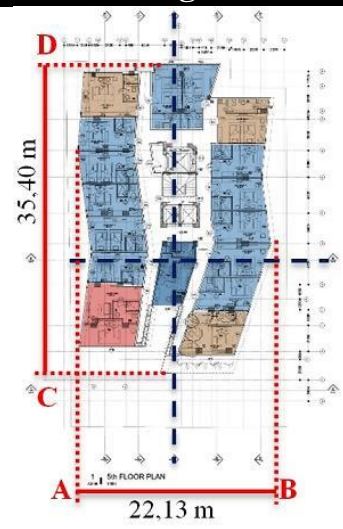

Denah Lt. 5

AB 22,13

$$
\begin{aligned}
& \frac{\mathrm{AB}}{\mathrm{CD}}=\frac{22,13}{35,40}=0,6251 \\
& \begin{aligned}
\frac{\mathrm{CD}}{\mathrm{AB}+\mathrm{CD}} & =\frac{35,40}{22,13+35,40} \\
& =0,6153
\end{aligned}
\end{aligned}
$$

Rata-rata

$$
=(0,6251+0,6153) / 2
$$$$
=0,6202
$$

Selisih

$$
\begin{aligned}
& =0,6202-0,6180 \\
& =0,0022
\end{aligned}
$$

Proporsi baik

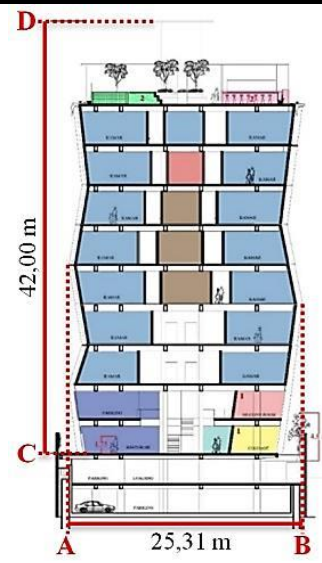

\section{Potongan BB}

$\frac{\mathrm{AB}}{\mathrm{CD}}=\frac{25,31}{42,00}=0,6026$

$$
\begin{aligned}
\frac{\mathrm{CD}}{\mathrm{AB}+\mathrm{CD}} & =\frac{42,00}{25,31+42,00} \\
& =0,6240
\end{aligned}
$$

Rata-rata

$$
\begin{aligned}
& =(0,6026+0,6240) / 2 \\
& =0,6133
\end{aligned}
$$

Selisih

$=0,6180-0,6133$

$=0,0047$

Proporsi baik 
Tabel 4. Analisis Proporsi dan Skala Bangunan Hotel U Janevalla (lanjutan)

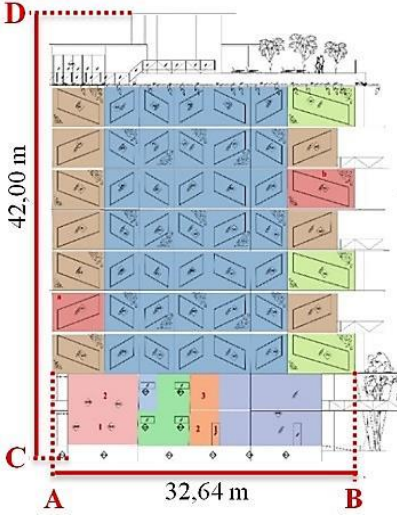

Tampak Kanan (Barat)

$\frac{\mathrm{AB}}{\mathrm{CD}}=\frac{32,64}{42,00}=0,7771$

$$
\begin{aligned}
\frac{\mathrm{CD}}{\mathrm{AB}+\mathrm{CD}} & =\frac{42,00}{32,64+42,00} \\
& =0,5627
\end{aligned}
$$

Rata-rata

$$
=(0,7771+0,5627) / 2
$$$$
=0,6699
$$

Selisih

$$
\begin{aligned}
& =0,6699-0,6180 \\
& =0,0519
\end{aligned}
$$

Proporsi cukup baik

Lantai yang dapat dihitung proporsinya adalah lantai dengan fungsi penting/ khusus yaitu Ground Floor, Mezzanine, dan Pool Plan, serta lantai dimana terdapat jenis kamar yang dianalisis yaitu Lt. 2 (deluxe), Lt. 5 (grand deluxe), dan Lt. 6 (superior).

Acuan pembobotan berdasarkan selisih antara rata-rata proporsi dengan nilai ideal golden section 0,6180 yaitu:

Selisih $0,0000-0,0010=$ sangat baik, bobot 4

Selisih $0,0010-0,0100=$ baik, bobot 3

Selisih $0,0100-0,1000=$ cukup, bobot 2

Selisih $>0,1000=$ kurang, bobot 1

\begin{tabular}{lllr} 
Desain & Proporsi & Perkalian Bobot & Nilai \\
6 denah & 4 baik +2 cukup baik & $(4 \times 3)+(2 \times 2)$ & 16 \\
\hline 2 tampak & 1 baik +1 cukup baik & $(1 \times 3)+(1 \times 2)$ & 5 \\
\hline 2 potongan & 1 baik +1 cukup baik & $(1 \times 3)+(1 \times 2)$ & 5 \\
\hline 2 3D & 1 baik + 1 cukup baik & $(1 \times 3)+(1 \times 2)$ & 5 \\
\hline Total & 7 baik + 5 cukup baik & & 31 \\
\hline Ideal & & $4 \times 12$ & 48 \\
\hline Persentase & & $(31 / 48) \times 100 \%$ & $\mathbf{6 4 , 5 8 \%}$ \\
\hline
\end{tabular}

Persentase estetika ditinjau dari proporsi bangunan $\mathbf{6} \mathbf{6 4 , 5 8 \%}$.

Perhitungan skala yang dilakukan adalah skala manusia, dimana dimensi bangunan yang terlihat dibandingkan terhadap tinggi manusia 1,75 m. Dimensi bangunan 14,46 hingga 22,29 kali lipat tinggi manusia, dan pengamat dapat merasakan seluruh tampilan visualnya dengan jarak tertentu/ skala kota (skala baik). Kendala yang ada untuk mengamati dalam skala kota adalah terhalangnya view oleh objek-objek di sekitarnya terutama bangunan dan vegetasi.

Persentase estetika ditinjau dari skala bangunan $=\left(\begin{array}{lll}3 & \times & 3\end{array}\right) / 12=$ $\mathbf{7 5 , 0 0 \%}$

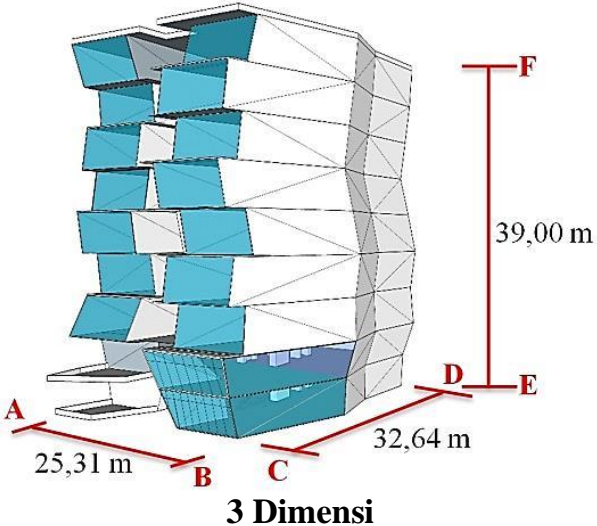

Terdapat perbedaan elevasi pada site maka tinggi bagian depan bangunan 42,00 m sedangkan bagian belakangnya $39,00 \mathrm{~m}$.

$$
\begin{aligned}
& \frac{\mathrm{AB}}{\mathrm{EF}}=\frac{25,31}{39,00}=0,6490 \\
& \begin{aligned}
\frac{\mathrm{EF}}{\mathrm{AB}+\mathrm{EF}} & =\frac{39,00}{25,31+39,00} \\
& =0,6064
\end{aligned}
\end{aligned}
$$

Rata-rata

$$
\begin{aligned}
& =(0,6490+0,6064) / 2 \\
& =0,6277
\end{aligned}
$$

Selisih

$$
\begin{aligned}
& =0,6277-0,6180 \\
& =0,0097
\end{aligned}
$$

Proporsi baik

$$
\begin{gathered}
\frac{\mathrm{CD}}{\mathrm{EF}}=\frac{32,64}{39,00}=0,8369 \\
\begin{array}{c}
\frac{\mathrm{EF}}{\mathrm{CD}+\mathrm{EF}}=\frac{39,00}{32,64+39,00} \\
=0,5444
\end{array}
\end{gathered}
$$

Rata-rata

$$
\begin{aligned}
& =(0,8369+0,5444) / 2 \\
& =0,6907
\end{aligned}
$$

Selisih

$$
\begin{aligned}
& =0,6907-0,6180 \\
& =0,0727
\end{aligned}
$$

\section{Proporsi cukup baik}

Skala berdasarkan lebar bangunan $=$

$$
\frac{\mathrm{AB}}{1,75}=\frac{25,31}{1,75}=14,46
$$

Skala berdasarkan panjang bangunan $=$

$$
\frac{C D}{1,75}=\frac{32,64}{1,75}=18,65
$$

Skala berdasarkan tinggi bangunan $=$

$$
\frac{\mathrm{EF}}{1,75}=\frac{39,00}{1,75}=22,29
$$


Proporsi ruang dihitung berdasarkan dimensi denah dan potongan, sedangkan skalanya dibandingkan dengan tinggi manusia dewasa $1,75 \mathrm{~m}$, lihat Tabel 5 .

Tabel 5. Analisis Proporsi dan Skala Kamar Tidur Hotel U Janevalla

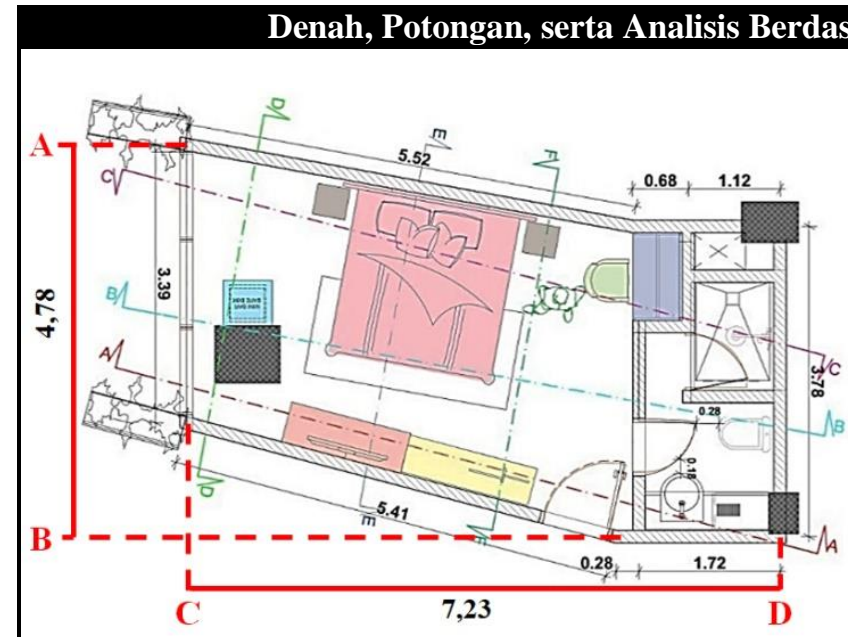

Denah kamar superior
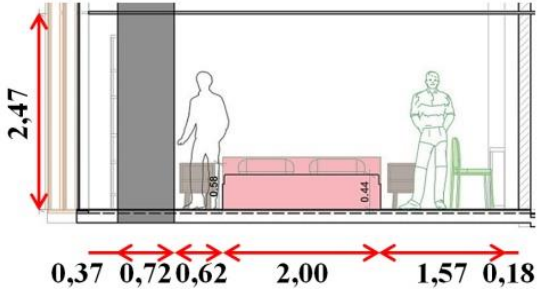

Potongan BB

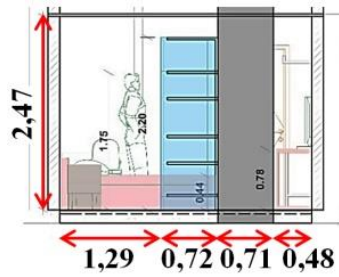

Potongan DD

$$
\begin{aligned}
& \frac{\mathrm{AB}}{\mathrm{CD}}=\frac{4,78}{7,23}=0,6611 \\
& \begin{aligned}
\frac{\mathrm{CD}}{\mathrm{AB}+\mathrm{CD}} & =\frac{7,23}{4,78+7,23} \\
& =0,6020
\end{aligned}
\end{aligned}
$$

Rata-rata

$$
\begin{aligned}
& =(0,6611+0,6020) / 2 \\
& =0,6316
\end{aligned}
$$

Selisih

$$
=0,6316-0,6180
$$$$
=0,0136
$$

Proporsi cukup baik

$$
\begin{aligned}
& \frac{\text { Tinggi }}{\mathrm{AB}}=\frac{2,47}{4,78}=0,5167 \\
& \begin{aligned}
\frac{\mathrm{AB}}{\text { Tinggi }+\mathrm{AB}} & =\frac{4,78}{2,47+4,78} \\
& =0,6593
\end{aligned}
\end{aligned}
$$

Rata-rata

$$
\begin{aligned}
& =(0,5167+0,6593) / 2 \\
& =0,5880
\end{aligned}
$$

Selisih

$$
=0,6180-0,5880
$$$$
=0,0300
$$

Proporsi cukup baik

$$
\begin{aligned}
& \frac{\text { Tinggi }}{\mathrm{CD}}=\frac{2,47}{7,23}=0,3416 \\
& \begin{aligned}
\frac{\mathrm{CD}}{\text { Tinggi }+\mathrm{CD}} & =\frac{7,23}{2,47+7,23} \\
& =0,7454
\end{aligned}
\end{aligned}
$$

\begin{tabular}{|c|c|c|c|}
\hline$\frac{\mathrm{AB}}{\mathrm{CD}}=\frac{5,19}{6,95}=0,7468$ & $\frac{\text { Tinggi }}{\mathrm{AB}}=\frac{2,47}{5,19}=0,4759$ & $\frac{\text { Tinggi }}{\mathrm{AB}}=\frac{2,47}{6,95}=0,3554$ & $\begin{array}{l}\text { Perhitungan skala: } \\
\text { Berdasarkan lebar ruang } \\
\text { AB } 5,19\end{array}$ \\
\hline $\begin{aligned} \frac{\mathrm{AB}+\mathrm{CD}}{\mathrm{A}} & =\frac{0,19+6,95}{5,19+95} \\
& =0,5725\end{aligned}$ & $\begin{aligned} \frac{\text { Tinggi }+\mathrm{AB}}{2,47+5,19} & =\frac{5}{2,19} \\
& =0,6775\end{aligned}$ & $\begin{aligned} \frac{A D}{\text { Tinggi }+\mathrm{AB}} & =\frac{0,35}{2,47+6,95} \\
& =0,7378\end{aligned}$ & $\begin{array}{l}1,75 \\
\text { Berdasarkan panjang ruang }\end{array}$ \\
\hline $\begin{array}{l}\text { Rata-rata } \\
\qquad=(0,7468+0,5725) / 2 \\
\quad=0,6596\end{array}$ & $\begin{array}{l}\text { Rata-rata } \\
\qquad=(0,4759+0,6775) / 2 \\
\quad=0,5767\end{array}$ & $\begin{array}{l}\text { Rata-rata } \\
\quad=(0,3554+0,7378) / 2 \\
\quad=0,5466\end{array}$ & $\begin{array}{l}\frac{C D}{1,75}=\frac{6,95}{1,75}=3,97 \\
\text { Berdasarkan tinggi ruang }\end{array}$ \\
\hline $\begin{array}{l}\text { Selisih } \\
\quad=0,6596-0,6180 \\
\quad=0,0416 \\
\text { Proporsi cukup baik }\end{array}$ & $\begin{array}{l}\text { Selisih } \\
\quad=0,6180-0,5767 \\
\quad=0,0413 \\
\text { Proporsi cukup baik }\end{array}$ & $\begin{array}{l}\text { Selisih } \\
\quad=0,6180-0,5466 \\
\quad=0,0714 \\
\text { Proporsi cukup baik }\end{array}$ & $\begin{array}{l}\frac{\text { Tinggi }}{1,75}=\frac{2,47}{1,75}=1,41 \\
\text { Skala baik }\end{array}$ \\
\hline
\end{tabular}

$$
\begin{aligned}
& \text { Rata-rata } \\
& \quad=(0,3416+0,7454) / 2 \\
& \quad=0,5435
\end{aligned}
$$

Selisih

$$
=0,6180-0,5435
$$

$=0,0745$
Perhitungan skala:

Berdasarkan lebar ruang

$$
\frac{\mathrm{AB}}{1,75}=\frac{4,78}{1,75}=2,73
$$

Berdasarkan panjang ruang

$$
\frac{\mathrm{CD}}{1,75}=\frac{7,23}{1,75}=4,13
$$

Berdasarkan tinggi ruang $\frac{\text { Tinggi }}{1,75}=\frac{2,47}{1,75}=1,41$

Skala baik

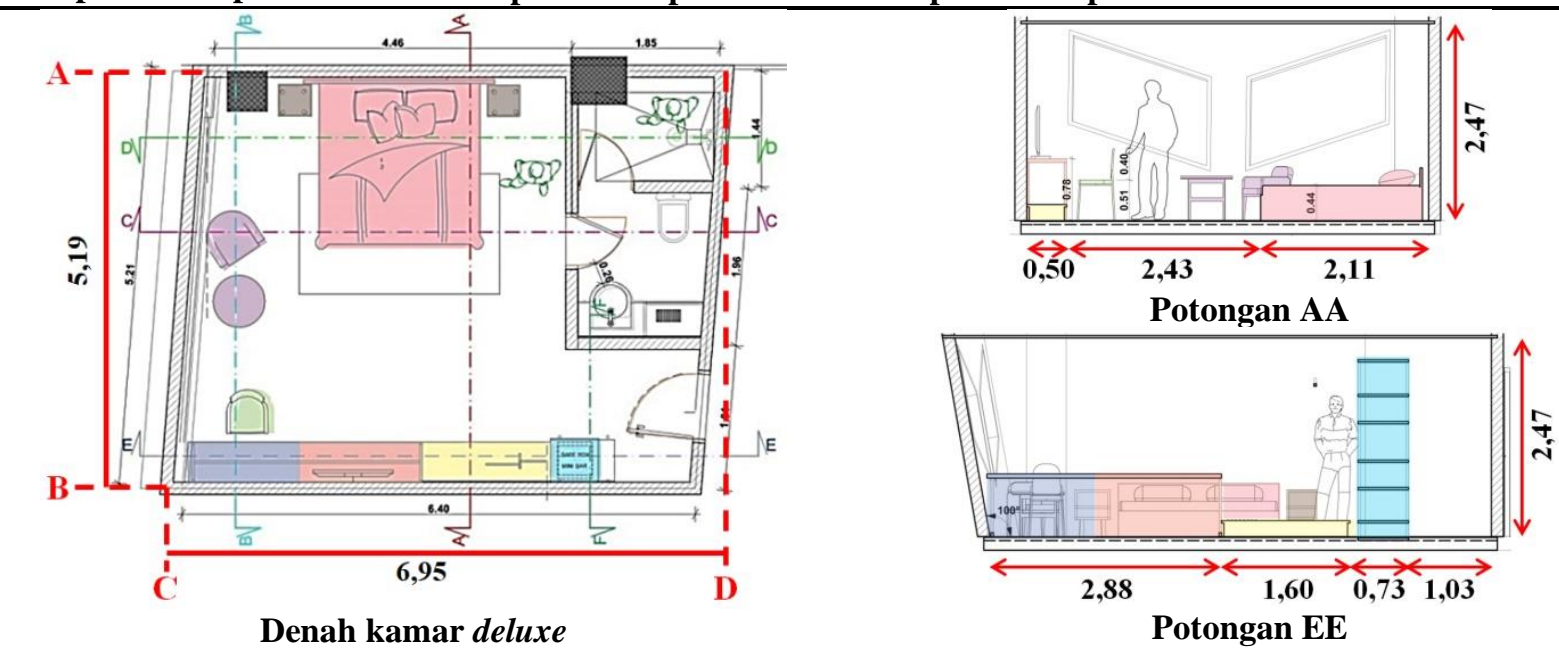


Tabel 5. Analisis Proporsi dan Skala Kamar Tidur Hotel U Janevalla (lanjutan)

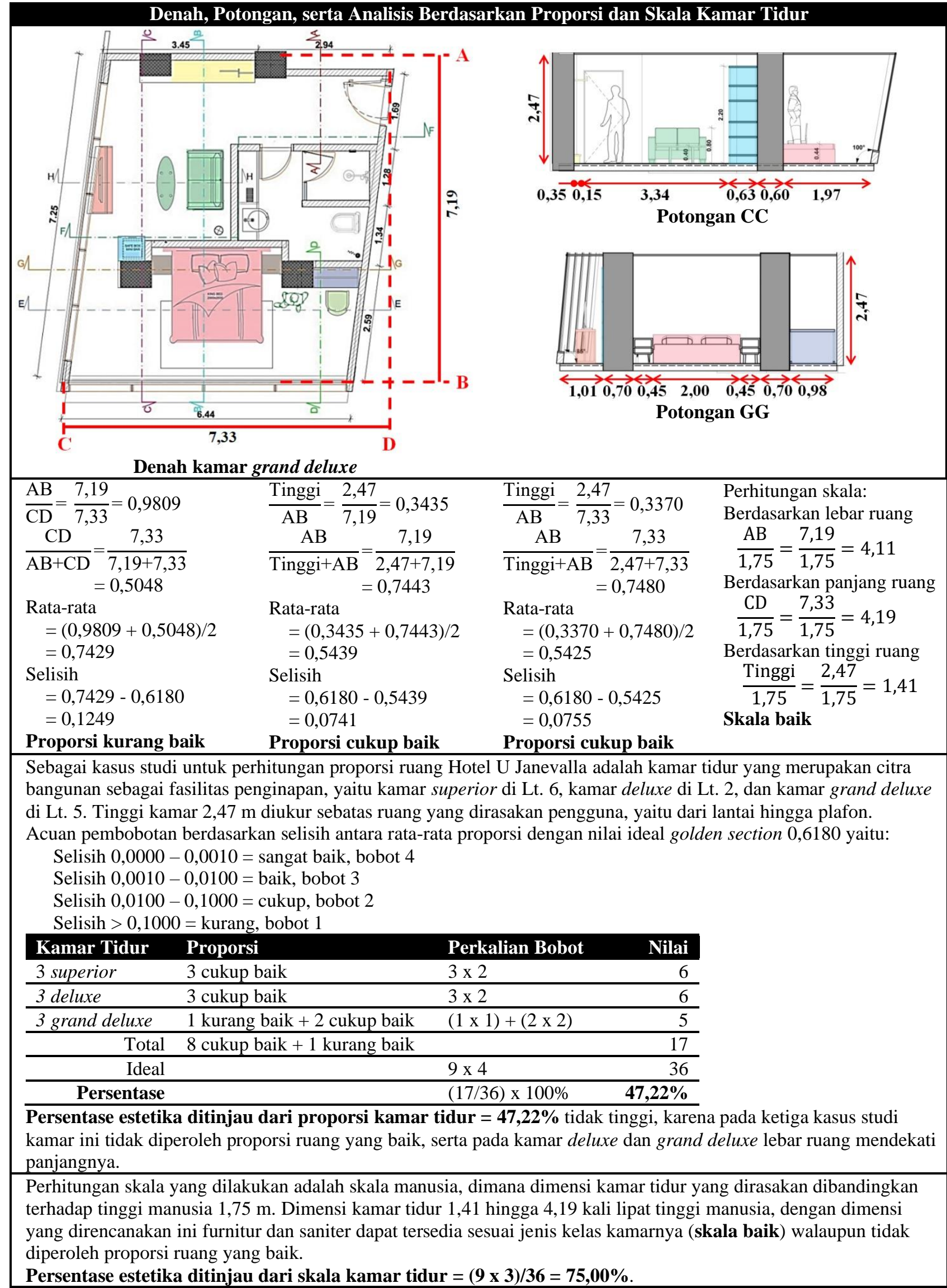




\subsection{Kenyamanan Spasial (Ruang Gerak) Hotel U Janevalla bagi Pengguna}

Ruang yang menjadi kasus studi adalah kamar tidur. Jenis kamar tidur di Hotel U Janevalla dibedakan berdasarkan luas ruang dan kelengkapan interiornya. Semua jenis ruang telah dilengkapi tempat tidur king size atau double size, penggantung pakaian (standing hanger), rak simpan (pantry), rak simpan koper (luggage rack), meja nakas (bedside table), meja kerja atau rias, dan kursi (armchair). Pada kamar deluxe terdapat tambahan meja (coffee table), sedangkan pada kamar grand deluxe terdapat tambahan set meja- sofa. Saniter di bathroom ketiga jenis kamar ini sama, terdapat washtafel, shower, dan kloset, perbedaannya ada di luas ruangnya. Berikut analisis kenyamanan spasial (ruang gerak) pada kamar tidur yang dilakukan terpisah antara bedroom dan bathroom, lihat Tabel 6.

Tabel 6. Analisis Kenyamanan Spasial (Ruang Gerak) Kamar Tidur Hotel U Janevalla

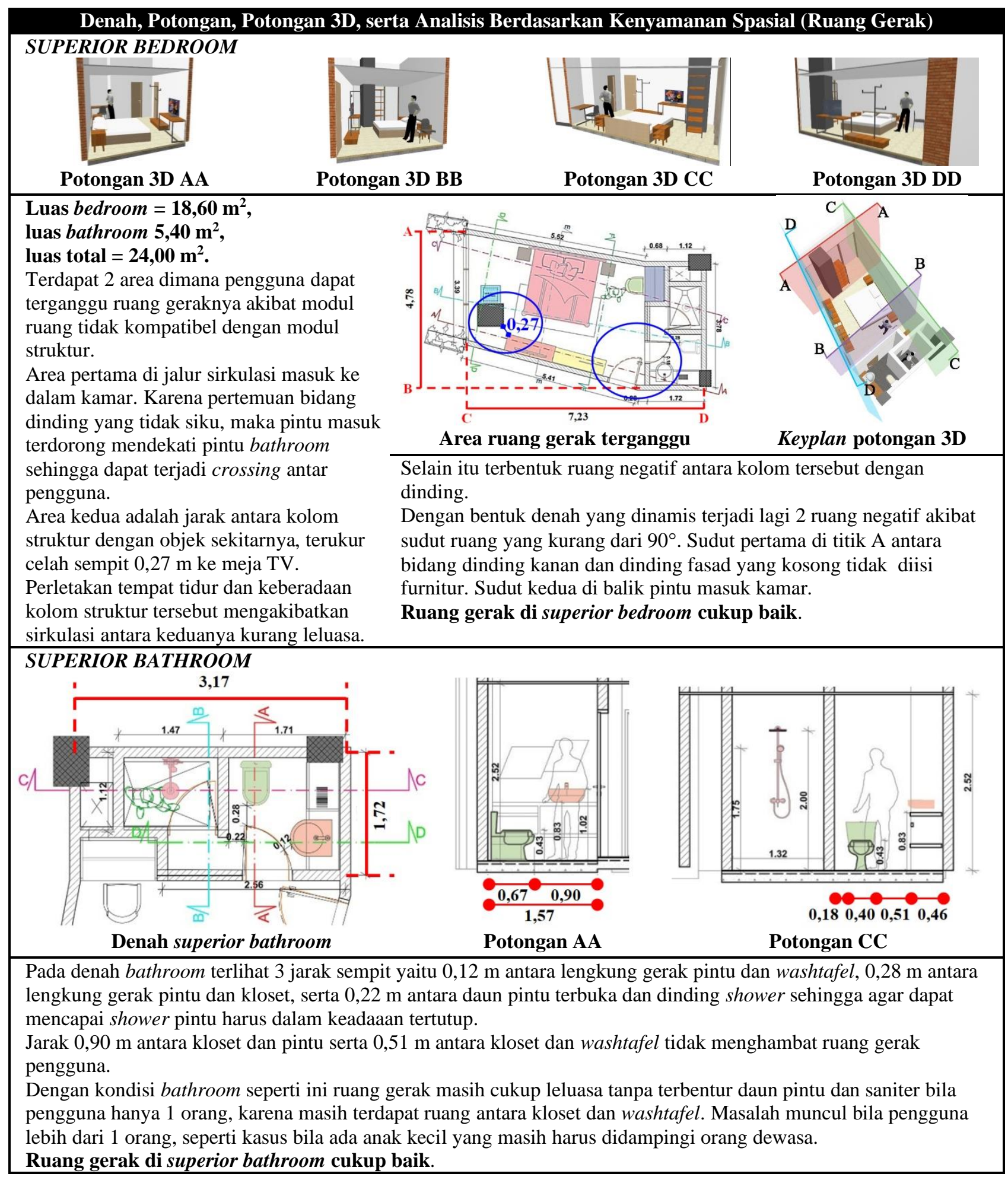


Tabel 6. Analisis Kenyamanan Spasial (Ruang Gerak) Kamar Tidur Hotel U Janevalla (lanjutan)

Denah, Potongan, Potongan 3D, serta Analisis Berdasarkan Kenyamanan Spasial (Ruang Gerak)
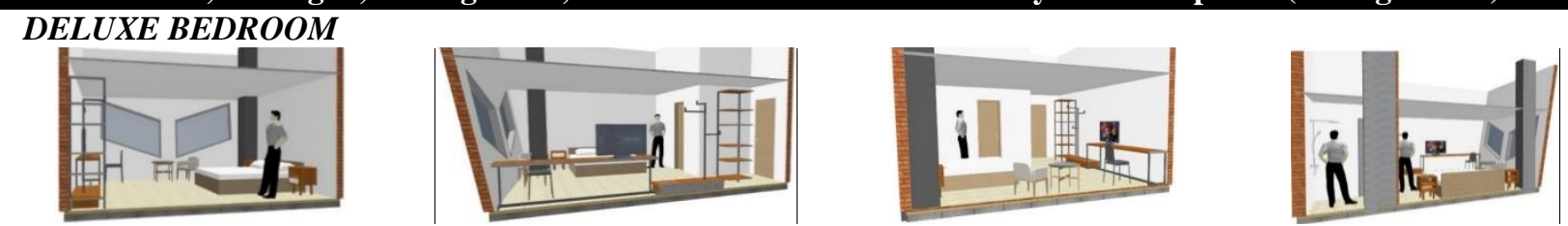

Potongan 3D AA

Potongan 3D BB

Potongan 3D CC

Potongan 3D DD

Luas bedroom $=22,44 \mathrm{~m}^{2}$,

luas bathroom $6,66 \mathrm{~m}^{2}$,

luas total $=32,50 \mathrm{~m}^{2}$.

Terdapat 1 area dimana pengelola dapat terganggu ruang geraknya saat melakukan pembersihan ruang. Area ini berupa celah sempit 0,12 $\mathrm{m}$ dan 0,15 $\mathrm{m}$ di samping kolom struktur, akibat modul ruang yang tidak kompatibel dengan modul struktur.

Dengan bentuk denah yang dinamis terjadi sudut ruang yang kurang dari $90^{\circ}$, tetapi masih cukup besar tidak menimbulkan ruang negatif.

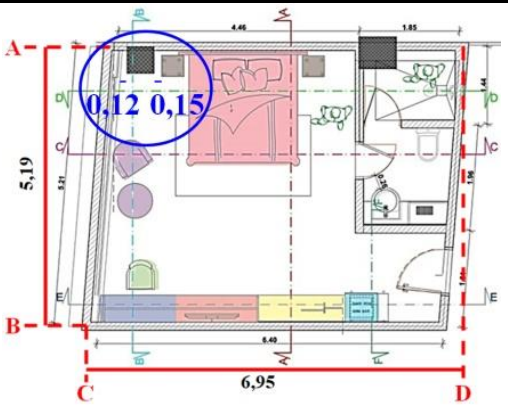

Area ruang gerak terganggu

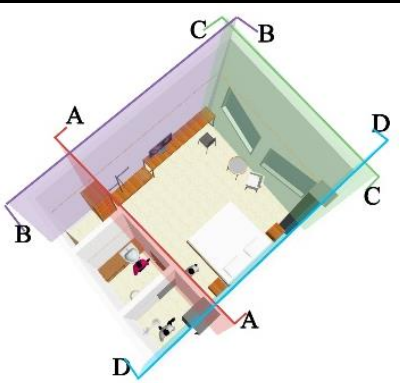

Keyplan potongan 3D Ruang gerak di deluxe bedroom baik.

\section{DELUXE BATHROOM}

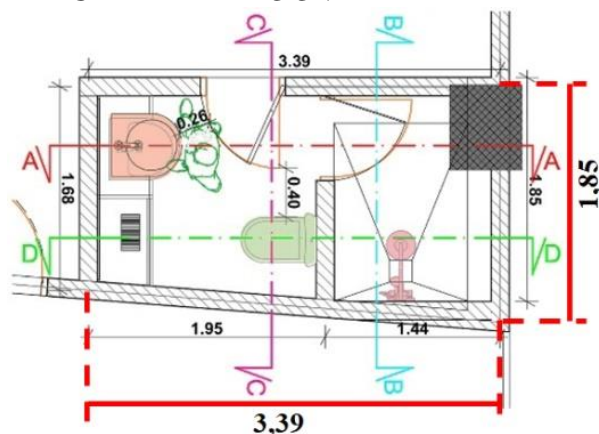

Denah deluxe bathroom

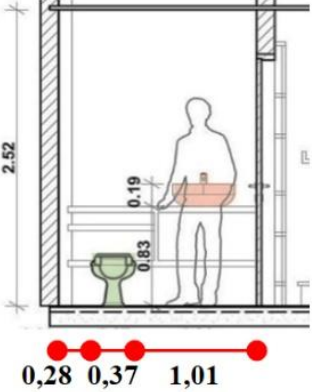

Potongan CC

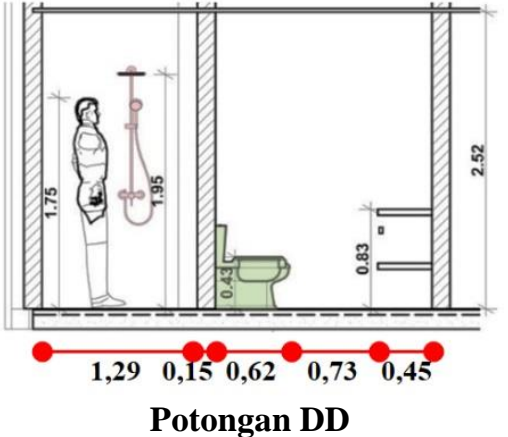

Potongan DD

Pada denah bathroom terlihat 2 jarak sempit yaitu 0,26 $\mathrm{m}$ antara lengkung gerak pintu dan washtafel serta 0,40 $\mathrm{m}$ antara lengkung gerak pintu dan kloset. Jarak 1,01 m antara kloset dan pintu serta 0,73 m antara kloset dan washtafel tidak menghambat ruang gerak pengguna.

Dengan kondisi bathroom seperti ini ruang gerak masih cukup leluasa tanpa terbentur daun pintu dan saniter bila pengguna hanya 1 orang, karena masih terdapat ruang antara kloset dan washtafel.

Ruang gerak di deluxe bathroom baik.

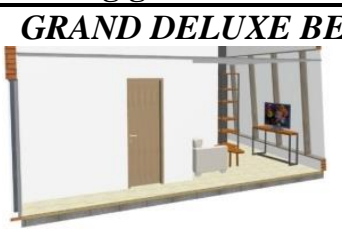

Potongan 3D AA
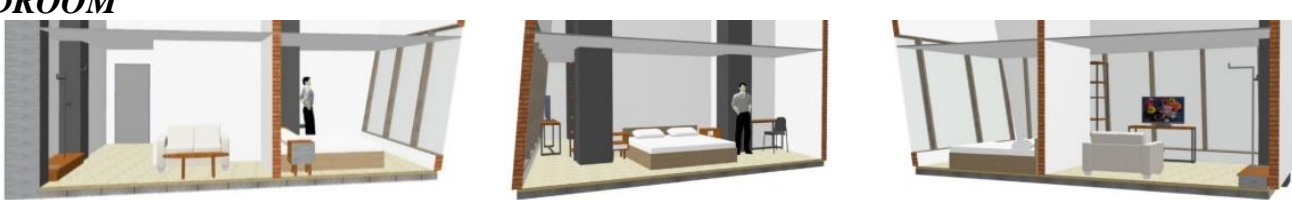

Luas bedroom $=30,62 \mathrm{~m}^{2}$ luas bathroom $10,88 \mathrm{~m}^{2}$, luas total $=43,00 \mathrm{~m}^{2}$.

Terdapat 1 area dimana pengguna dapat terganggu ruang geraknya, yaitu jalur sirkulasi antara lemari dan meja TV yang hanya selebar $0,52 \mathrm{~m}$

Dengan bentuk denah yang dinamis terjadi sudut ruang yang kurang dari $90^{\circ}$, tetapi masih cukup besar tidak menimbulkan ruang negatif. Ruang gerak di grand deluxe bedroom cukup baik.

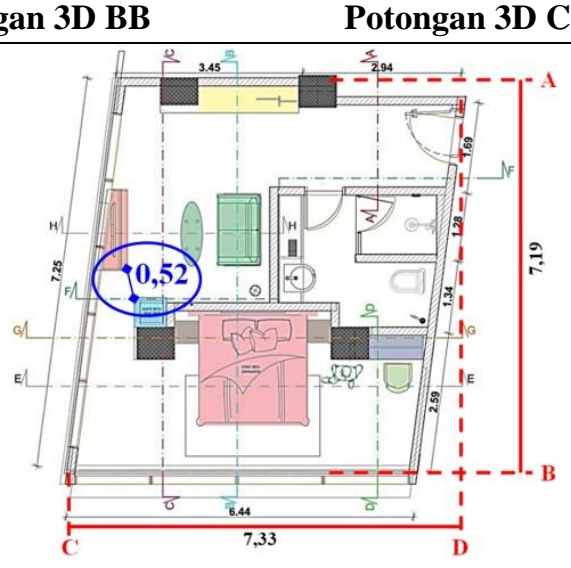

Area ruang gerak terganggu

保

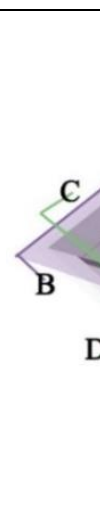

Keyplan potongan 3D 
Tabel 6. Analisis Kenyamanan Spasial (Ruang Gerak) Kamar Tidur Hotel U Janevalla (lanjutan)

Denah, Potongan, Potongan 3D, serta Analisis Berdasarkan Kenyamanan Spasial (Ruang Gerak)

GRAND DELUXE BATHROOM

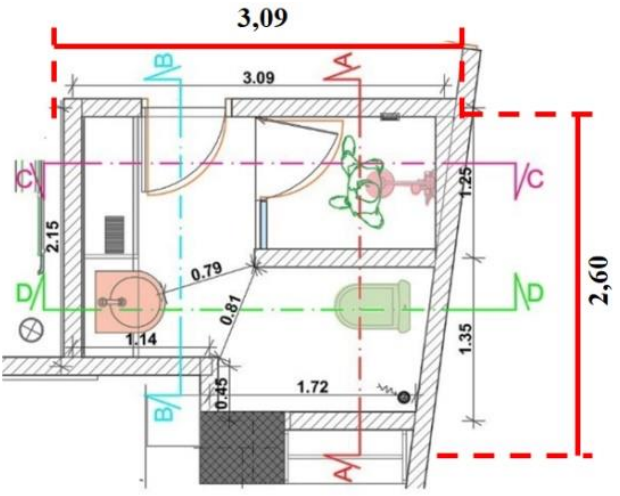

Denah grand deluxe bathroom

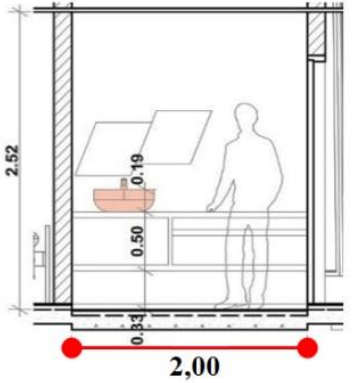

Potongan BB

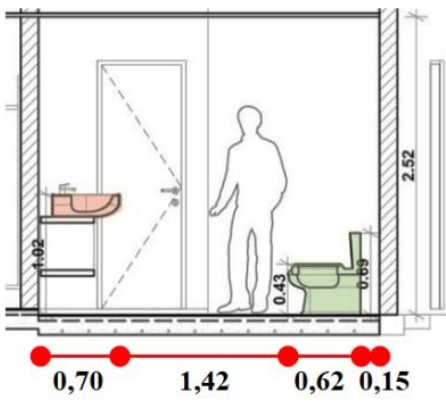

Potongan DD

Pada denah bathroom terlihat 2 jarak yaitu 0,79 $\mathrm{m}$ antara washtafel dan ujung dinding shower serta $0,81 \mathrm{~m}$ pada jalur sirkulasi menuju kloset. Jarak 2,00 m antara pintu dan dinding di seberangnya serta 1,42 $\mathrm{m}$ antara kloset dan washtafel tidak menghambat ruang gerak pengguna.

Dengan kondisi bathroom seperti ini ruang gerak sudah leluasa tanpa terbentur daun pintu dan saniter walaupun terdapat pengguna hingga 2 orang.

Ruang gerak di grand deluxe bathroom sangat baik.

Berikut perhitungan pembobotan kenyamanan spasial (ruang gerak) pada kamar tidur.

\begin{tabular}{lllr} 
Kamar Tidur & Kenyamanan Spasial & Perkalian Bobot & Nilai \\
Superior bedroom & Cukup baik & $1 \times 2$ & 2 \\
\hline Superior bathoom & Cukup baik & $1 \times 2$ & 2 \\
\hline Deluxe bedroom & Baik & $1 \times 3$ & 3 \\
\hline Deluxe bathroom & Baik & $1 \times 3$ & 3 \\
\hline Grand deluxe bedroom & Cukup baik & $1 \times 2$ & 2 \\
\hline Grand deluxe bathroom & Sangat baik & $1 \times 4$ & 4 \\
\hline Total & 1 sangat baik + 3 cukup baik + 2 baik & 16 \\
\hline Ideal & & $6 \times 4$ & 24 \\
\hline \multicolumn{2}{r}{ Persentase } & $(16 / 24) \times 100 \%$ & $\mathbf{6 6 , 6 7 \%}$ \\
\hline
\end{tabular}

Kenyamanan spasial (ruang gerak) pada kamar tidur $=66,67 \%$.

Sumber gambar denah: Budi Pradono Architect, 2018, diolah Sumber gambar potongan dan potongan 3D serta analisis: penulis, 2021

\section{Kesimpulan}

Berikut pembobotan dari seluruh variabel penelitian. Sebagai acuan rata-rata persentase yaitu $\geq 80,00 \%$ $=$ sangat baik; 65,00\% hingga $<80,0 \%=$ baik; 50,00\% hingga $<65,00 \%=$ cukup baik; dan $<50,00 \%=$ kurang baik.

Tabel 7. Pembobotan Variabel Penelitian

\begin{tabular}{|c|c|c|c|}
\hline Variabel & Persentase & Kelompok Variabel & $\begin{array}{l}\text { Rata-rata } \\
\text { Persentase }\end{array}$ \\
\hline Transformasi bentuk denah dan gubahan massa & $100,00 \%$ & \multirow{3}{*}{$\begin{array}{l}\text { Transformasi gubahan massa } \\
\text { dinamis }\end{array}$} & \multirow{3}{*}{$\begin{array}{r}100,00 \% \\
\text { Sangat baik }\end{array}$} \\
\hline Transformasi bentuk ruang & $100,00 \%$ & & \\
\hline Transformasi bentuk massa bangunan & $100,00 \%$ & & \\
\hline Estetika ditinjau dari proporsi bangunan & $64,58 \%$ & \multirow{4}{*}{$\begin{array}{l}\text { Estetika berdasarkan proporsi } \\
\text { dan skala }\end{array}$} & \multirow{4}{*}{$\begin{array}{r}57,95 \% \\
\text { Cukup baik }\end{array}$} \\
\hline Estetika ditinjau dari skala bangunan & $75,00 \%$ & & \\
\hline Estetika ditinjau dari proporsi kamar tidur & $47,22 \%$ & & \\
\hline Estetika ditinjau dari skala kamar tidur & $75,00 \%$ & & \\
\hline $\begin{array}{l}\text { Kenyamanan spasial (ruang gerak) pada kamar } \\
\text { tidur }\end{array}$ & $66,67 \%$ & $\begin{array}{l}\text { Kenyamanan spasial (ruang } \\
\text { gerak) pada kamar tidur }\end{array}$ & $\begin{array}{r}66,67 \% \\
\text { Baik } \\
\end{array}$ \\
\hline Rata-rata persentase & $78,56 \%$ Baik & Rata-rata persentase & 78,56\% Baik \\
\hline
\end{tabular}

Sumber: penulis, 2021 
Penerapan bentuk gubahan massa bangunan yang dinamis melalui strategi dekonstruksi/ dekomposisi pada hotel U Janevalla berhasil diterapkan dengan baik (nilai 78,56\%), dimana diperoleh proses transformasi gubahan massa dinamis dengan sangat baik (nilai 100,00\%), estetika berdasarkan proporsi dan skala dengan cukup baik (nilai 57,95\%), serta kenyamanan spasial (ruang gerak) bagi pengguna di kamar tidur dengan baik (nilai 6667\%).

Keberhasilan penerapan bentuk gubahan massa bangunan yang dinamis belum tentu dapat menjamin perolehan nilai estetika ditinjau dari proporsi dan skala yang sangat baik. Agar nilai estika ini dapat ditingkatkan, perlu dilakukan penerapan proporsi ruang dan bangunan yang lebih tepat/ presisi.

Keberhasilan penerapan bentuk gubahan massa bangunan yang dinamis juga berpengaruh terhadap perolehan kenyamanan spasial (ruang gerak) pengguna dan efektifitas pemanfaatan ruang. Tata letak interior yaitu furnitur dan saniter harus diatur sedemikian rupa dengan sebaik-baiknya agar dengan ruang yang tersedia tidak menghasilkan celah dan jalur sirkulasi yang sempit. Bentuk ruang yang dinamis dapat menimbulkan terjadinya ruang negatif, akibat pertemuan antar bidang dinding atau antara bidang lantai dan dinding yang membentuk sudut kurang dari $90^{\circ}$ juga modul ruang yang tidak kompatibel dengan modul struktur, maka sebaiknya tata letak dan dimensi interior harus disesuaikan dengan sudut ruang yang terjadi serta modul struktur bangunan sebaiknya dapat didesain lebih fleksibel mengikuti modul ruang.

Agar bentuk gubahan massa dinamis pada bangunan khususnya hotel dapat diterapkan dengan lebih optimal, diperlukan penelitian lebih mendalam terkait strategi transformasi bentuk, perhitungan proporsi dan skala terutama pada ruang, termasuk kenyamanan spasial menggunakan teori ergonomi.

\section{Ucapan Terima Kasih}

Kami sebagai penulis mengucapkan terima kasih sebesar-besarnya atas ijin dan bantuan yang telah diberikan oleh pimpinan dan staf Hotel U Janevalla sehingga dapat melakukan survei meliputi pengamatan, pengukuran, dan dokumentasi yang semuanya sangat diperlukan dalam penyusunan penelitian ini. Terima kasih sebesar-besarnya juga kami ucapkan kepada Bapak Budi Pradono - Studio Budi Pradono Architects (BPA), selaku arsitek Hotel U Janevalla yang telah menjadi nara sumber terutama untuk gambar kerja denah, tampak, dan potongan yang sangat diperlukan dalam penelitian ini.

\section{Referensi}

Agustin, R. K., Firzal, Y., \& Aldy, P. (2018). Penerapan Prinsip Form Follow Functon pada Pusat Penelitian dan Budidaya Kelapa Hibrida di Indragiri Hilir. Jurnal Online Mahasiswa Fakultas Teknik Universitas Riau, 5(2), 1-6.

Ching, F. D. K. (2008). Arsitektur: Bentuk, Ruang, dan Tatanan. Edisi Ketiga. Jakarta: Erlangga (dalam bahasa Indonesia).

Hendrarto, T., Rachman, M., \& Sulastio, O. (2012). Kajian Proporsi Ruang-Dalam Bangunan Baru Hotel Concordia Bandung. Reka Karsa, 1(1), 1-12.

Loho, W. D., Poluan, R. J., \& Egam, P. P. (2015). Gedung Konvensional di Tomohon (Optimalisasi Form Follow Function oleh Louis Sullivan). Jurnal Arsitektur Daseng Unsrat Manado, 4(2), 170-177.

Najoan, S. J., \& Mandey, J. (2011). Transformasi sebagai Strategi Desain. Media Matrasain, 8(2), 117-130.

Nurfadilah, C. \& Rachmaniyah, N. (2016). Redesain Interior Hotel Bisnis dengan Konsep Minimalis Montana. Jurnal Sains dan Seni ITS 5(2), 2337-3520 (2301-928X Print), 188-192.

Pujantara, R. (2015). Pengaruh Preseden Arsitektur Dunia terhadap Karakteristik Bentuk Fasade Bangunan di Kota Makassar. Langkau Bentang, 2(15), 116-136.

Putra, G. H. (2014). Efektivitas Ruang Dalam Rumah Tipe 36 Ditinjau dari Perletakan Perabot terhadap Ruang Gerak Penghuni. E-Journal Graduate Unpar, 1(2), 201-212.

Sani, A.A., Supriyadi, B., \& Rukayah, R. S. (2015). Bentuk dan Proporsi pada Perwujudan Arsitektur Vernakular Bugis. Teknik Sipil dan Perencanaan, 17(2), 99-110.

Westin Hotel \& Resort. (2016). Scheme A Generation 4. New York: Starwood Hotels \& Resorts Worldwide, inc. 